\title{
Unveiling the parents' perceptions on no-homework policy in Nangan Elementary School
}

\author{
Revelando as percepções dos pais sobre a política de não dever de casa na Nangan Elementary School \\ Revelando las percepciones de los padres sobre la política de no hacer tareas en la escuela primaria Nangan
}

\author{
Roy Galenzoga Garing, LPT, MAEE \\ roygaring777@gmail.com \\ Nangan Elementary School, Davao Oriental, Philippines \\ https://orcid.org/0000-0001-5389-5811
}

\begin{abstract}
This qualitative-phenomenological study was initiated to explore and understand the lived experiences and different perceptions of parents on no-homework policy in Nangan Elementary School, Nangan, Governor Generoso, Davao Oriental. Subsequently, this qualitative exploration hoped to draw out conclusions on the perceptions of the parents. The data source in this study derived from seven (7) research participants for the in-depth interview and another seven (7) parents for the focus group discussion. The research participants of this study were the selected Grade Five to Grade Six parents in Nangan Elementary School who were usually having many assignments compared to lower grade levels. The following themes emerged from analysis based in the perspectives of participant interviews: no-homework policy can be optional; no-homework policy is unfavorable and unhelpful to students; no-homework policy causes students to become irresponsible; and no-homework policy causes less learning among students. Concerning the experiences of parents in dealing with the assignments of their children, five major themes were manifested such as: having difficulties in answering homework; being able to help children; having fun while doing the assignment; being unable to finish work or chores; and bonding opportunity. Moreover, the participants about their challenges in dealing with the assignments of their children, four major themes emerged: understanding how to answer the lesson; having balance and time management; giving encouragement; and having follow-ups and rules. Lastly, their suggestions as regards the nohomework policy revealed four emergent themes: parents should always be responsible and helpful to their children; parents should have time management and balance; teachers should give appropriate, simple and uncostly homework; and teachers should give homework to students for continued learning.
\end{abstract}

Keywords: education, no-homework policy, Grade 5 \& 6 parents, qualitative phenomenological research, thematic analysis, Nangan Elementary School, Governor Generoso, Davao Oriental, Philippines

\section{RESUMO}

Este estudo qualitativo fenomenológico foi iniciado para explorar e compreender as experiências vividas e diferentes percepções dos pais sobre a política de não-dever de casa na Escola Primária de Nangan, Nangan, Governador Generoso, Davao Oriental. Posteriormente, esta exploração qualitativa esperava tirar conclusões sobre as percepções dos pais. A fonte de dados neste estudo derivou de sete (7) participantes da pesquisa para a entrevista em profundidade e outros sete (7) pais para a discussão do grupo focal. Os participantes da pesquisa deste estudo foram os pais selecionados da quinta à sexta série da Escola Primária Nangan, que geralmente tinham muitas atribuições em comparação com as séries mais baixas. Os seguintes temas emergiram da análise com base nas perspectivas das entrevistas dos participantes: a política de não dever de casa pode ser opcional; a política de não dever de casa é desfavorável e prejudicial aos alunos; a política de não dever de casa faz com que os alunos se tornem irresponsáveis; e a política de não dever de casa causa menos aprendizagem entre os alunos. No que se refere às experiências dos pais no trato com as atribuições dos filhos, cinco grandes temas se manifestaram, tais como: dificuldade em responder aos deveres de casa; ser capaz de ajudar crianças; se divertindo ao fazer a tarefa; ser incapaz de terminar o trabalho ou tarefas domésticas; e oportunidade de vínculo. Além disso, aos participantes sobre seus desafios em lidar com as atribuições de seus filhos, emergiram quatro grandes temas: entender como responder à lição; ter equilíbrio e gerenciamento de tempo; dando encorajamento; e ter acompanhamentos e regras. Por fim, suas sugestões quanto à política de não-dever de casa revelaram quatro temas emergentes: os pais devem ser sempre responsáveis e prestativos com seus filhos; os pais devem ter controle do tempo e equilíbrio; os professores devem dar trabalhos de casa apropriados, simples e baratos; e os professores devem dar lição de casa aos alunos para que aprendam continuamente.

Palavras-chave: educação, política de não-dever de casa, pais de $5^{\mathrm{a}}$ e $6^{\mathrm{a}}$ séries, pesquisa fenomenológica qualitativa, análise temática, Nangan Elementary School, Governador Generoso, Davao Oriental, Filipinas 


\section{INTRODUCTION}

Homework has always been the most controversial educational issue and continuously a debated topic of discourse, yet, paying attention to the educational strategies would result in meaningful and purposeful effects in the students' achievements (Fan et al., 2017). However, homework can be construed as any academic works entrusted by a schoolteacher intended for students to complete tasks during non-instructional hours. Thus, homework likely has an indispensable influence on students' educational trajectories.

As Tam and Chan (2016) revealed from the recent studies, homework endured being polarized. Among the most controversial issues today, there were some lawmakers tried to push the "No-Homework Policy" where teachers, students, parents, and even politicians have emerged themselves the bandwagon and the burning issue.

In the United States, parents have their own problems with homework on how to encourage their children to finish it. Moreover, parents who are having difficulties when it came to verifying the completion of homework and understanding the tasks that the students must do. Thus, family stress was examined in the context of children's homework load of parents' perceptions of their capacity to assist their children with homework. So, the National Education Association and the National Parent Teacher Association have weighed in, endorsing the "ten-minute rule" with a daily limit of 10 minutes of homework per grade level for elementary pupils (Walker, 2017).

In the Philippines, homework has been a topic of burning discussion and concern for learners, parents, teachers, and administrators. The diverse understandings and attitudes about homework by these stakeholders often result in disagreement. However, parents believed homework was far from enhancing students' learning, and it was a burden only for students. Paris (2019) stated that homework assignments could deprive students and parents of precious quality time for rest, relaxation with their families and interaction after school hours, and even on the weekend.

In Governor Generoso, Davao Oriental especially in Nangan Elementary School, homework has been still the hotly debated issues that ostensibly lead to arguments in several schools. Most teachers believed that homework would help pupils as essential leverage to scholastic performances. Yet, parents believed that it would only de-escalate the learning abilities of their children and do result in poor academic performances in school for they are the ones who only answer the assignments at home. However, homework would only give negative ramifications that result in family stress and loss of interest in learning.

The fuss about the burning and controversial issue has evidently affected and bothered me as a researcher. I am very concerned about the results of this issue. Undeniably, homework has been a part of pupils' lives since the beginning of formal schooling.

Thus, there were studies that concluded the positive and negative effects of homework on the scholastic performances of students. Some showed that the most direct positive effect of homework is that it can enhance retention and understanding and always be beneficial to the students (Nunez et al., 2015). Conversely, some showed that increasing homework workloads does not necessarily equate to academic success nor the amount of time that students spend on homework each night (Valle et al., 2016). Hence, there is still a need to conduct a study to draw out conclusions in addressing the certain issue.

Moreover, society may embrace the no-homework policy and how it may also help in the holistic structure of the child. This study can be the basis in making inferences about what this policy will benefit the general public and how essential homework is to the students. This will also 
give an opportunity to all parents with their students to be fully aware of the societal impact in this research.

With all these compelling reasons, this urges me to conduct the study which seeks to explore and understand the different perspectives of parents as regards to the controversial issue. Additionally, I consider this study as urgent and germane, for there are no studies yet conducted on No-Homework Policy in Governor Generoso, Davao Oriental.

\section{Statement of the Problem}

In order to unveil the parents' perspectives on no-homework policy, the following questions were used to guide this phenomenological study:

1. What are the perspectives of parents on No-Homework Policy?

2. What are the experiences of parents in dealing with the assignments of their students?

3. How do the parents cope with the challenges they encountered in dealing with the assignments of their students?

4. What are the suggestions of parents on No-Homework Policy that can be shared to others?

\section{THEORETICAL FOUNDATION}

This study is gleaned from the study conducted in Western Cape Province, South Africa by Pfeiffer in 2018. This study seeks to determine whether a no-homework policy will validate a positive or negative effect on school children and intended to determine whether a no-homework policy would be beneficial to South African schools. An interpretive approach to a case study was in place, where an interview was conducted with teachers and the head of the curriculum.

This case study considered replacement exercises executed at the school to compensate for the homework no longer given to the learners. This study found that no-homework has left a more positive effect on learners. However, this study argues that no-homework will be a disadvantage in the future. Further, this study sought motivating factors that influence learners in becoming successful. Finally, this study proposes that some form of homework ought to be in place in order to help the learner in many aspects of their future life.

This study is also gleaned through the "Guidelines on Giving Homework or Assignment to All Public Elementary School Pupils," other known as DepEd Memorandum No. 392, series 2010, the Department of Education (DepEd) reiterates its commitment to the holistic development of learners inside and outside the classroom. The said issuance aims to enable learners to have more quality time with their parents, family, and friends by limiting the homework or assignment to a reasonable quantity on school days and by eliminating the same during weekends.

In this memorandum, it is in this regard that the Department supports the no-homework policy proposed by legislators from the House of Representatives. By ensuring that they complete all assignments and projects in school, the no-homework policy enables the learners to find a balance between their academic development and personal growth by having ample time for enjoyable activities with family. However, the Department of Education will further study the other provisions of the bills to determine the repercussions on the current teaching and learning process. 
This is also gleaned from the proposition conducted by Núñez et al. (2015) which explains about parental involvement. Núñez et al. (2015) analyzed parents' involvement in terms of control and support that spanned elementary through high school levels. In the study, control was described as pressure on students to complete homework, and support was interpreted as favorable help.

In this concept, parental involvement has a positive and negative influence on the academic achievement of the students depending on its condition. Furthermore, parents believed that homework only hassles on their part, knowing that they still had their own activities to be done at home. Thus, they believed that it would only lower the learning abilities of their children if they are going to interfere in the completion of homework.

\section{METHODOLOGICAL PROCEDURES}

This chapter presents the methodological paradigms to understand the perceptions of parents of elementary school students regarding the no-homework policy. Included in this chapter are the research design, research participants, role of the researcher, data sources, data collection procedure, data analysis, the trustworthiness of the study, and the ethical considerations which were highlighted in the conduct of this phenomenological study.

\subsection{Research Design}

This present study is qualitative in nature. Qualitative research is a process of naturalistic inquiry that seeks an in-depth understanding of social phenomena within their natural setting (Creswell, 2013). Further, it is an inquiry process of understanding based on distinct methodological traditions of inquiry that explore a social or human problem. The researcher built a complex, holistic picture, analyze words, reports detailed views of informants, and conducts the study in a natural setting.

This study is a type of phenomenological research. A phenomenological study focuses on the experiences of a person or group in response to a phenomenon (Patton, 2002). In this study, the phenomena of the experiences of parents concerning no-homework policy were examined. The study is phenomenological in nature, focusing on the phenomena of homework.

The qualitative research method using a phenomenological approach is considered appropriate for this research. This is the most appropriate design for the study because I gathered information in the different perceptions and insights of the Grade Five and Grade Six parents in one of the schools in Governor Generoso, Davao Oriental, concerning the no-homework policy. Gall and Borg (2007), as posited by McCormick (2014) that the qualitative research method enables the research to explore, examine, and assist in understanding a phenomenon and the lived experiences of a group of people within the context of a phenomenon. Thus, an in-depth interview was used for the data collection.

\subsection{Respondents and Sampling}

As recommended by Creswell (2013) that phenomenological research conducted in a heterogeneous group should be a minimum of 3 to a maximum of fifteen (15) persons. Participants for this phenomenological study were selected through the use of a purposive sampling technique. Purposive sampling is a common method chosen by qualitative researchers to ensure that selection of participants provides a vast amount of information about a phenomenon (Palinkas et al., 2015). I utilized purposive sampling in determining the participants to select key and specific individuals, who provided the best information required to answer the research questions. 
The criteria in selecting the participants include grade five to grade six parents who had three (3) to six (6) children ages 6 to 12 years old enrolled in the same school in Governor Generoso, Davao Oriental. Moreover, the research participants of this study were the parents whose children are usually having many assignments compared to lower grade levels. Additionally, I conducted an initial survey to teachers and students from the aforementioned grade levels of the elementary school to select parent-participants who were doing many assignments together with their children and who were also willing to participate in the study. Thus, I selected parents who expressed either a positive view or a negative perception about the nightly homework of their children. There were fourteen (14) participants in the study specifically, seven (7) for the in-depth interview and another seven (7) for the focus group discussion.

\subsection{Research Instrument}

This study is part of an indispensable project regarding homework in elementary school. According to Creswell (2013) that qualitative researchers use different ways of collecting the data and should take into consideration in the nature of investigation, such as by observations, through personal interviews and reliable documents. The present study required several data collections focused on fifth and sixth grade parents' perspectives on no-homework policy. The present study included data collected from parents through in-depth interviews and focus group interviews. These interviews were to explore and understand the parents' perspectives in the context of no-homework policy.

The data source in this present study is derived from 7 research participants for the IDI of parents and another 7 participants for FGD. According to Rosenthal (2016), in-depth interviews involve the posing of open-ended questions and follow-up probes designed to obtain an in-depth understanding of participants' experiences, perceptions, opinions, feelings, and knowledge.

I certainly ensured to construct their interview guide to provide essential information to answer the research questions during the interview and, thus, to obtain the purpose of the study. I utilized a voice recorder to carefully obtain data and to avoid misconceptions about the participants' responses. Ultimately, I ensured that all interviews and documents were transcribed and examined completely to distinguish important themes.

\subsection{Data Gathering Procedures}

In the conduct of this study, as mentioned by Creswell (2007) that qualitative researchers will be tied up in a series of activities in the process of collecting data. Thus, an essential pace that I considered was to look for the feasibility of the materials needed, the research participants who were included in the study, and the setting where I conducted my study to gather and obtain essential information to answer the purpose of this study.

As a researcher, I took smooth proceedings in obtaining important detailed data in the pursuit of the completion of the research study. First, I sought permission from the office of the Schools Division Superintendent and from the District Supervisor to be able to conduct my study in one of the schools in Governor Generoso, Davao Oriental. Moreover, I asked permission from the office of the School Principal to get the approval in conducting my study, and to administer an interview with the selected participants.

Second, parent-participants were identified with the use of purposive sampling method. I ensured to select key participants to obtain essential information about the perspectives and insights 
on No-Homework Policy. Then, I gave the consent form to the participants and asked permission from them to read and sign the informed consent before involving them in the research.

Third, I collected all the data based on the research questions. I used the validated research questions as a way for me to attain essential and adequate data during the participants' interviews. I used open-ended questions in getting further pivotal information as regards the parents' perceptions on no-homework policy. As cited by McCormick (2014), the primary source of data collection is through interviews, both individual and group interviews, since its purpose is to describe a shared experience. Thus, this helped the participants to have a chance to share their views and opinions in a greater extent concerning the subject area.

Fourth, I utilized an audio recorder as an aid for me to get all information from the participants. As posited by Audu (2016) that the purpose of the audio-taped recording was to ensure the data from the participants are kept and stored, and then transcribed after the interview. Additionally, I recorded interviews on a laptop for safety in case of malfunction, and this was absolutely helpful in transcribing my data. Further, I also considered note taking in order to get the research participants' non-verbal responses. Also, I transcribed verbatim or word-for-word responses from the participants to make data more precise and accurate.

Fifth, thematic analysis was done. I was assisted by my adviser to ensure that the responses of my participants were certainly analyzed based on the core ideas.

\subsection{Data Analysis}

The current phenomenological study sought to explore and understand the parents' perspectives on no-homework policy. After completing the transcriptions of the in-depth interview and focus groups, the analysis of data took place and can assist with the coding process. According to Rosenthal (2016) that qualitative analysis must include "thick description." I included a thick description in my study, for it is one way of indulging readers into the participants' responses of the in-depth interviews or focus group discussions. This kind of research instrument helped me in analyzing the interpretations of the participants to increase the reliability and consistency of the documents.

To increase the reliability and credibility of this research, thematic analysis was utilized for the data analysis process. I used thematic analysis as suggested by Braun and Clarke (2006), for it is a method to identify the responses of the research participants, themes within the data and categories. This is commonly used in qualitative analysis. From the analysis of the parents' perspectives on no-homework policy, I obtained important information about the impact on the students of having no amount of homework assignments to be carried out during non-school hours or even every night at home.

The collected data were reviewed, synthesized, and documented in order to store confidential and detailed information from the participants. I analyzed and examined the qualitative data collectively to provide a holistic picture. All data were collected such as the answer of the research participants from the interview, the audio recordings, and the results were analyzed according to the research questions.

\section{RESULTS AND DISCUSSION}

This chapter deals with the presentation and analysis of data collected from document analysis, both in-depth interviews and a focus group discussion on the perspectives of parents on 
No-Homework Policy. Majority of the participants acknowledged that homework has the potential to contribute positively to learning and learner outcomes if appropriately practiced. The data collected were presented and analyzed in line with the research questions. Hence, this chapter reported the findings of the current study. It was organized by the researcher in order to fully understand the themes that emerged within each research question.

\section{Parents' Perceptions on No-Homework Policy}

From the data collected from the perspectives of parents on no-homework policy in one of the schools in Governor Generoso, Davao Oriental, four (4) major themes emerged as reflected in Table 1 namely: 1) no-homework policy can be optional; 2) no-homework policy is unfavorable and unhelpful to students; 3) no-homework policy causes students to become irresponsible; and 4) nohomework policy causes less learning among students.

Table 1

Major Themes and Core Ideas on the Perspectives of Parents on No-Homework Policy

\begin{tabular}{|c|c|}
\hline Major Themes & Core Ideas \\
\hline $\begin{array}{l}\text { No-Homework Policy can be } \\
\text { Optional }\end{array}$ & $\begin{array}{l}\text { Assignments should be optional so that it will } \\
\text { not be difficult to help and guide children for } \\
\text { their lessons. } \\
\text { Parents would like homework to be optional so } \\
\text { that they will not worry at all in making } \\
\text { assignments. } \\
\text { Not all assignments given by a teacher are easy } \\
\text { for the parents. } \\
\text { Homework should be optional so that it may not } \\
\text { have a hard time answering the assignments } \\
\text { when children need help. } \\
\text { Not all lessons should have assignments to do so. } \\
\text { Homework should be optional to have little time } \\
\text { for the children. } \\
\text { Students should not have multiple assignments to } \\
\text { make at home. }\end{array}$ \\
\hline $\begin{array}{l}\text { No-Homework Policy is Unfavorable } \\
\text { and Unhelpful to Students }\end{array}$ & $\begin{array}{l}\text { No-homework policy is unfavorable to parents. } \\
\text { The policy does not help children's knowledge } \\
\text { to develop. } \\
\text { No-homework will not give essential benefits to } \\
\text { students. } \\
\text { The children's learning will discontinue. } \\
\text { The students will just play and run out of school. } \\
\text { No-homework would be unhelpful to students' } \\
\text { learning progress. } \\
\text { The purpose of schooling will be defeated. }\end{array}$ \\
\hline $\begin{array}{l}\text { No-Homework Policy Causes } \\
\text { Students to Become Irresponsible }\end{array}$ & $\begin{array}{l}\text { The students would just really feel at ease } \\
\text { watching movies and playing with their } \\
\text { cellphones. } \\
\text { No-homework brings no good to students' } \\
\text { studies and will make them become } \\
\text { irresponsible. } \\
\text { No-homework will find reading more difficult. }\end{array}$ \\
\hline
\end{tabular}




\begin{tabular}{|l|l|}
\hline & $\begin{array}{l}\text { Children will have enormous time for cellphones } \\
\text { and strolling. } \\
\text { Children will do nothing at home but only } \\
\text { playing around. } \\
\text { Children will be irresponsible to open their } \\
\text { books and to their studies. }\end{array}$ \\
\hline \multirow{5}{*}{$\begin{array}{l}\text { The learning of one's child from school } \\
\text { discontinues or stops. } \\
\text { The children will learn nothing without having } \\
\text { homework. Among Students } \\
\text { There is no hope of learning to happen without } \\
\text { assignments. } \\
\text { The students will not be able to learn more. } \\
\text { The interests of the children to study will vanish. } \\
\text { There will be no follow up of the lessons taught } \\
\text { by the teacher at night. }\end{array}$} \\
\hline
\end{tabular}

\section{No-Homework Policy can be Optional}

We are all fully aware of the fact that everything has its own way of purpose. It could be good or bad thing to offer. Hence, no-homework policy can be optional emerged as one of the themes in the perspectives of the parents.

IDI-01 expressively believed that,

"Mas maayo g'yud nga naay assignments pero adunay kapilian lang sir para dili lisod ineg tabang sa mga bata para ma guide pud sila kung unsa ang ilang leksiyon."

(It is much better to have assignments but it should be optional, so that it will not be difficult for us to help and guide them for their lessons.)

IDI-03 shared her thoughts,

"Para sa akoa, puwede optional siya nga naay homework para ang katong ginikanan nga ok ra sa ilaha walay homework dili sila mabahala."

(For me, homework should be optional so that those parents who are fine on having no assignments will not be worried at all.)

IDI-04 expressed her view,

"Adunay kapilian kay dili tanang homework na gihatag sa teachers makabalo usab ang tanang ginikanan.”

(It should be optional because not all assignments given by a teacher are easy for the parents.)

IDI-06 asserted,

"Para sa ako sir optional lang g'yud nga naay homework sir kay para dili daghan ang assignment ug basin maglisod pud ko ug tubag kung magpatabang sila."

(For me, homework should be optional so that I may not have a hard time answering their assignments when they need help.) 
Moreover IDI-07 suggested that,

"Siguro puwede pa siya optional sir, dili man siguro tanang leksiyon kailangan jud ug assignment. Pero dili lang g'yud siya walaon sir."

(Maybe, it can be optional because not all lessons need assignments to do so. But not really to eliminate homework.)

FGD-01 also shared her insights that,

"Siguro optional lang sir, para mahatagan pa kaming mga ginikanan ug bisag gamay nga oras sa mga bata."

(Maybe optional, so that we will be given little time for our children.)

FGD-02 also shared,

"Puede ra man siguro optional sir aron dili kaayo daghan ila assignments nga pagabuhaton."

(It can be optional so that they do not have multiple assignments to make at home.)

\section{No-Homework Policy is Unfavorable and Unhelpful to Students}

Based on their responses to the question on the perspectives of parents regarding to the nohomework policy, it was revealed that some parents militated against the no-homework practice.

IDI-01 expressed,

"Dile g'yud ko makapasalig sa no-homework policy sa mga bata kay as ginikanan man gud gusto nako nga ang akong mga anak makakat-on g'yud sa mga teachers. Ug ang assignments makatabang kini aron mamaayo ang akong mga anak nga estudyante intawun."

(I am unfavorable to no-homework policy. As a parent, I want my children to learn from the teachers and the assignments will help them become better students.)

In line with this, IDI-02 also expressed that,

"Ang ako g'yud masulti dili gyud kini maayo sa mga bata ug dili kini makatabang sa ilang kahibalo. Isip usa ka inahan, dili ko musugot mabalaod kini. Unsaon nalng ilang pag study sir?"

(I can definitely say that this is not really good for the children and it does not help in developing their knowledge. As a mother, I do not want to make it a policy.)

IDI-03 emotionally said,

"Na maguol g'yud ko pagmaayo kung wagtangon nila ang mga assignments sa mga estudyante. Kung ginikanan nga concern sa mga anak mas malipay g'yud unta kung naay homework ang akong mga anak. Murag lain g'yud sakong paminaw sir, makasubo pamalandungon kay wala gyud silay makuha anang no-homework nila."

(I feel worried if homework will be eliminated. If the parents are concerned with their children, they should be happy having homework. I truly feel sorry because no-homework will not give essential benefits.)

IDI-05 added her sentiments,

“Bation g'yud nako sir ug panghinayang ug kaguol kay dili naman mapadayon ang learnings sa mga bata sa balay gikan sa school. Na! Dile gyud ni makaayo sa ila sir." 
(I am truly worried for the children's learning will discontinue. And it would not really be favorable to them.)

FGD-01 firmly narrated her response,

"Dili g'yud ko pabor sa palisiya nga walay buluhaton sa balay akong mga anak tungod kay magdula ra na sila didto ug manglaag ra gikan sa eskuwelahan, For sure wala g'yuy makat-unan ug samot ang mga estudyante."

(I am not in favor about the policy of having no assignments to be taken at home because they will just play after school. For sure, students would not learn from it.)

Another participant shared her answer.

"Mabag-ohan ko sir kay naad baya ko sa una nga naa jud mi homework. Tabang man gud para dugang kat-on. Kung mao gyud ni ila gusto sir, walay kamaohan ang bata.” (FGD-02)

(I am not used to having no-homework because we really have assignments before. And if nohomework will be practiced, it would be unhelpful to students' learning progress.)

FGD-03 conveyed her answer,

"Murag wala nay pulos ilang pag eskuwela kay dili na ma-develop ang ilang mga nasabtan ug pag-abot sa balay imbes magtuon, diretso na na hinuon sa dula."

(The purpose of their schooling will be defeated because their learning will not be developed after class. Instead of studying at home, they will just be playing around.)

\section{No-Homework Policy Causes Students to Become Irresponsible}

Based on the perspectives of the participants, they believed that students become slothful in the faces of their studies. No-homework caught the attention of the participants that urged them to give some insights of the possibilities of having no-homework policy. Hence, the no-homework policy calls students to become irresponsible emerged as one of the themes in the perceptions of the parent-participants.

IDI-02 strongly expressed her ideas that,

"Hayahay ra kaayo ang mga bata mag sige rag tan-aw ug salida sa balay ug magsige ug dula sa ilang mga cellphones."

(They would just really feel at ease watching movies and playing with their cellphones which makes them irresponsible.)

Moreover, IDI-05 stated,

"Kung ang no-homework policy mapadayon, akong natan-aw na musamot ang katapulan sa ubang mga estudyante. Walay kaayohan ang mahatag niini sir."

(If no-homework continues, students will become irresponsible. It brings no good to their studies.)

IDI-07 shared,

"Para sa ako, mao kini ang makasamot sa bata na mahimong tapulan o di kaya maglisod na ug basa sila sir."

(For me, children will become irresponsible and will find reading more difficult.) 
FGD-02 narrated,

"Dili ko malipay g'yud sir kay sigurado ko akong mga anak mas dako pa na'g time sa cellphone ug laag sir."

(I am unhappy because for sure my children will have enormous time for cellphones and strolling.)

In addition, FGD-05 firmly believed and stated her notion that,

"Dili ko musugot ani sir. Diba mga inahan? Kung ang bata nato wlay homework, unsa nalang ang buhaton ineg uli sa balay? E di magdula...”

(If our children will have no-homework at all, what are they going to do at home? They will just play.)

FGD-06 also shared that,

"Dili gyud, kay wala nay rason para mangabre ug libro akong mga anak ud dili na sila responsable sa ilang pagtuon."

(Children will become irresponsible to open their books and also irresponsible to their studies.)

\section{No-Homework Policy Causes Less Learning Among Students}

As we go along on our interview some participants pointed out their perceptions that if nohomework policy will be terminated, they believed that the performances of one's child may be affected. Thus, the no-homework policy calls for less learning among students emerged as one of the themes in the perspectives of the participants.

In connection to this, IDI-01 articulated her response in this manner:

"Naay posibilidad nga dili sila makakat-on ug samot."

(There is a possibility that the learning of one's child from school discontinues or stops.)

IDI-02 also expressed with the same thought that,

"Wala gyuy makat-unan ang mga bata niini."

(The children will learn nothing without having homework.)

IDI-07 also stated,

"Pero sa akong panan-aw murag wala nato ginatudluan sila na ma-train o mo aayo kung dili g'yud nato hatagan sila ug assignments. Mogara pa na sila pagmaayo hinuon, wala na g'yuy kamaohan nga mahitabo sir."

(It seems to me that we do not teach them to be trained or to do well. If we do not give them assignments, there is no hope of learning to happen.)

FGD-01 revealed,

“Timan-e, wala g'yuy makat-unan ug samot ang mga estudyante."

(For sure, the students will not be able to learn more.)

FGD-03 conveyed her statement that,

"Mawala ang gana sa akong mga anak nga magtuon sa ilang mga natun-an." 
(The interests of my children to study will be vanished.)

Furthermore, FGD-04 shared,

"Wala na g'yud hinooy follow up sa pagkagabii sa mga leksiyon nga gitudlo ni teacher."

(There will be no follow-up of the lessons taught by the teacher at night.)

\section{Parents' Experiences in Dealing with the Assignments of their Students}

Participants resulted to different experiences in dealing with students' homework. Their experience tells them that they need to be responsible enough in helping their children to become better learners and to physically and emotionally support their children to enable to give quality time and elate good relationships with each other. They were able to understand the realities of life being parents of their children and were able to respond optimistically on the experiences they encountered.

Five (5) major themes were manifested such as: 1) having difficulties in answering homework; 2) being able to help children; 3) having fun while doing the assignment 4) being unable to finish work or chores; and 5) bonding opportunity.

Table 2 presents the major themes and core ideas of the experiences of parents in dealing with the assignments of their children.

\section{Table 2}

Major Themes and Core Ideas on the Experiences of Parents in Dealing with the Assignments of their Children

\begin{tabular}{|l|l|}
\hline \multicolumn{1}{|c|}{ Major Themes } & \multicolumn{1}{|c|}{ Core Ideas } \\
\hline Having Difficulties in Answering & $\begin{array}{l}\text { Children do not know how to answer their } \\
\text { assignments. } \\
\text { The assignment is very difficult and there is no } \\
\text { book as reference. } \\
\text { The teacher has something to look for and then it } \\
\text { really needs to be submitted on the next day for the } \\
\text { lesson. } \\
\text { Her child had no correct answers with the } \\
\text { assignments because of the power outage. } \\
\text { The assignments need internet connection to } \\
\text { research. } \\
\text { She had a hard time figuring out how to answer the } \\
\text { assignments. } \\
\text { Her children cry when they both find it difficult to } \\
\text { answer the homework. } \\
\text { The instructions of the assignments are not clear } \\
\text { on how to answer. }\end{array}$ \\
\hline
\end{tabular}




\begin{tabular}{|c|c|}
\hline Being Able to Help Children & $\begin{array}{l}\text { She will be able to help and guide her children } \\
\text { despite being busy at home. } \\
\text { The students will be excited to ask help from her } \\
\text { and do their assignments. } \\
\text { She will be able to help them through their } \\
\text { assignment. } \\
\text { She would love to help her children every time } \\
\text { they have their assignments. } \\
\text { She would be very delighted to help her children } \\
\text { complete their homework. } \\
\text { She has always been working so hard to help her } \\
\text { children as much as she can. } \\
\text { She could see the happiness of her children after } \\
\text { helping them. }\end{array}$ \\
\hline $\begin{array}{l}\text { Having Fun While Doing the } \\
\text { Assignment }\end{array}$ & $\begin{array}{l}\text { She felt okay and had fun helping with her } \\
\text { students' homework. } \\
\text { She feels it a good way because she is learning } \\
\text { while making an assignment. } \\
\text { She has joy supporting and joining with their } \\
\text { homework. } \\
\text { She finds it interesting that her children are more } \\
\text { intelligent compared to her. } \\
\text { She had fun making assignment with her children. } \\
\text { She enjoyed it very much seeing her children } \\
\text { working together while making their assignments. }\end{array}$ \\
\hline $\begin{array}{l}\text { Being Unable to Finish Work or } \\
\text { Chores }\end{array}$ & $\begin{array}{l}\text { She would not be able to finish her household } \\
\text { chores because of the homework that needs to be } \\
\text { researched on the internet. } \\
\text { She could not ask a favor from her children to help } \\
\text { do some chores. } \\
\text { She has a little child and works to prioritize. } \\
\text { She has many things to accomplish at home. } \\
\text { She gets upset to doing no other stuff at home. } \\
\text { My housework will be sacrificed due to loads of } \\
\text { assignments. }\end{array}$ \\
\hline Bonding Opportunity & $\begin{array}{l}\text { Making homework serves as their bonding. } \\
\text { She is very blissful with her children that they had } \\
\text { their bonding together. } \\
\text { She can talk her children more in life. } \\
\text { She can teach her children more that makes their } \\
\text { bonding becomes stronger. } \\
\text { They have unity at home. }\end{array}$ \\
\hline
\end{tabular}

\section{Having Difficulties in Answering Homework}

Parents are having uncertainties in the completion of homework. Hence, having difficulties in answering homework in the experiences of the participants emerged as one of the themes.

In line with this experience, IDI-02 shared that, 
"Siguro sir mao tong ang akong mga anak wala kabalo unsaon pag answer sa ilang mga assignments tapos ako dili pud ko kamao unsaon pag-answer."

(When my children do not know how to answer their assignments and I did not know how to answer it too.)

Other participants also shared their experiences,

"Kung lisod kaayo ang assignment unya walay mga libro sir nga kapangitaan sa kasgutan." (IDI03)

(When the assignment is very difficult then there is no book to be used as reference.)

"Kanang naay ipa assignment si teacher na lisod pangitaon tapos ipadala dayon pagkaugma kay gamiton sa lesson maglisod jud ko." (IDI-04)

(When the teacher has an assignment, which is difficult to look for and then to be submitted on the next day for their lesson, it is really difficult for me.)

IDI-07 expressed,

"Kanang mali akong natudlo sir kay nalipat ko kay tungod brownout man gud tapos nasuko siya sa ako kay namali siya sa assignment niya.”

(When I answered it wrong because of the power outage, he was upset at me because he had no correct answers with his assignments.)

In addition, FGD-02 shared,

"Kanang pangitaunon ang mga buluhaton kanang naay mga research, wala man gud mi internet sir."

(When the assignments need to research on the internet, it is really difficult because we do not have internet connection at all.)

FGD-03 added,

"Nakasinati ko sir nga dile ko kamao mo answer sa ilang assignments ug pati ako anak naglisod unsaon pag answer pud.”

(I have experienced that I cannot answer their assignments and I have a hard time figuring out how to answer it.)

However, FGD-04 narrated her experience,

"Na ang akong mga bata kay hilakan ko nila labi nag dili g'yud sila kamao o naglisod sila paganswer. Kay pati ako dili pud kamao."

(My children cried at me especially when they do not know, or they find it difficult to answer and I do not know how to answer it too.)

Other participant also added,

"Ang akong nasinati sir ug naglagot ko kay dili klaro ang instructions ug dili sila kamao mo answer sa ilang assignments maong naglisod pud kog tudlo tawn sa ila sir. Mao tong gikasab-an nako pagmaayo." (FGD-07) 
(I felt upset because the instructions are not clear and my children did not know how to answer their assignments, and so I found it difficult to answer too.)

\section{Being Able to Help Children}

It is innate for us to have the desires to help others in times of needs. Hence, for the participants, being able to help children emerged as one of the themes in the experiences of the parents.

IDI-01 expressively shared that,

"Malipay nalang sad ko maghuna-huna sir nga matabangan pud nako sila miskag busy ko kanunay sa balay."

(I am happy to think that I will still be able to help and guide them despite being busy at home.)

Furthermore, IDI-05 and IDI-06 added,

"Usa pa ma excite napud hinoon sila na magpatabang ug maghimo sa ilang assignments." (IDI05)

(Another thing is that they get excited to ask help from me and do their assignments.)

"Kanang makatabang ko sa pag answer sa homework sa mga bata sir." (IDI-06 )

(I will be able to help them through their assignment.)

IDI-07 narrated her feelings,

"Kanang nakita nako ang grado sa akong mga anak na taas. Ma happy nako niiana sir. Ug ganahan napud ko mutabang sa ila sir kung naay assignment miskag dili kaayo ko kabalo sir."

(When I see my children's scores are high, I would be very happy. I love to help them every time they have their assignments.)

FGD-02 shared,

"Kanang naa silay mahibaw-an gikan sako sir dako na na nga kalipay nako nga mahatag sa ila." (When they have learned something from me, I would be very delighted to help them complete their homework.)

FGD-04 stated her emotion,

"Kapoy pero gihimo na nako kanunay na trabaho sa pagtabang sa akong mga anak."

(It was tiresome, but I have always worked hard to help my children as much as possible.)

FGD-05 revealed her feelings,

"Sa ako pud nga case no kay makita nako nga malipayon sila human sa akong pagtabang kanila."

(In my case, I could see their happiness after helping them.)

\section{Having Fun While Doing the Assignment}

The next theme contained about the life of parents in dealing the assignments with their children. Hence, for the participants, having fun while doing the assignment emerged as the fifth theme in the experiences of the parents. 
IDI-01 expressed,

"Na sir Ok ra g’yud kaayo, mas nalipay hinuon ko nga makatabang sa ila."

(Sir, it is very okay! I am very happy helping them in their homework.)

IDI-03 also added,

"Para sa akoa maayo siya nga pamaagi sir kay sa pag-answer namo sa assignment kauban sa akong mga anak naka learn pud ko."

(I feel it a good way because while answering their assignments I am also learning.)

Further, FGD-01 happily said that,

"Ako magmalipayon nga mosuporta o moapil sa pagabuhaton nila sir.

(I am happy to support and join in the making of their homework.)

FGD-02 fascinatedly shared that,

"Mahimuot nalang ko kay mas bright pa sila."

(I find it interesting that they are more intelligent than I am.)

In addition, FGD-04 expressed her feeling,

"Nalingaw ko pagmaayo ba, hehehe... kay ang ilang assignment kay mag drawing ug tao tas ang pag drawing sakong anak kay murag abat sir... hehehe..."

(I had so much fun because one time their assignment was about to draw an ensemble of a person then my child's drawing was so ugly. It was so funny.)

Another participant expressed the same feeling,

"Malingaw ko makakita sa akong mga anak sir samtang maghimo ug assignments kay magtinabangay man sila sir.” (FGD-06)

(I enjoyed it very much seeing my children working together while making their assignments.)

\section{Being Unable to Finish Work or Chores}

The next theme emerged from the experiences of the participants is on the personal struggles of parents in the completion of household chores.

Relatedly, IDI-04 recalled her situation,

"Kanang time na ang assignments na ihatag ni teacher kay gikinahanglan ang internet, so ubanan jud nako ang bata sa internetan para ma research ug maprint ang assignment. Mao nang dili mahuman-human ang trabaho."

(There are times that the homework needs to be researched on the internet. So, I really need to go with them to search and print their needed assignments. Hence, I cannot finish my household chores.)

IDI-05 shared her emotions, 
"Makalagot pud usahay kay maglisod naman ko ug pamalihog ug sugo sa akong anak kay ang assignments wala pa nahuman. Naay time dili nako makatrabaho akong trabahuon kay nag assignment paman mi."

(Sometimes it is frustrating because I cannot ask a favor from my children to help me do some chores. Sometimes, I will not be able to finish my household works because we made their assignments.)

IDI-06 exclaimed that,

"Usik-usik ra sir sa panahon gyud labi na naa pakoy batang gamay ug trabahuon pud."

(It is just a waste of time especially that I still have a little child and works to prioritize. I could not finish because of homework.)

IDI-07 added,

"Isip ginikanan naa pud koy giatupag sa balay."

(As a parent, I still have many things to accomplish at home.)

Moreover, FGD-01 expressed her sentiment, "Ayaw lang kalain sir ha kay masungot pud ko kay naa pud koy dili matiwas sir ba nga trabaho..."

(I feel upset because I cannot do some other stuff at home because of homework.)

FGD-05 stated that,

"Mahimong makuhaan ang oras sa trabaho tungod daghan assignments sir pero ok lang para lang matabangan ang akong mga anak."

(My housework will be sacrificed due to loads of assignments but it is okay so that I can help my children.)

\section{Bonding Opportunity}

This theme contained some of the participants who genuinely believed a favorable juncture of having homework as a way of fostering parent-child bond and an avenue in elating the relationship among parents and children while they are in the process of making homework. Hence, bonding opportunity emerged as the first theme in the experiences of the parents.

In relation to this, IDI-01 expressed that,

"Sir, ang dile g'yud nako makalimtan samtang nagtabang ko sa akong mga anak kay ang among bonding na pud."

(The most unforgettable moment every time I helped in making their assignments is the bonding that we had with each other.)

IDI-03 shared her experiences that,

"Sir malipayon kaayo ko kauban sakong mga anak ug naka bonding pud mi.

(I am very blissful with my children for we had also our bonding together.)

Further, FGD-02 also expressed,

"Ok ra sir kay maistoryahan nako sila unsay angay buhaton ug time pud nako nga ma bonding nako sila miskag sa kadaghan ug trabahuon.” 
(I can talk to them more in life and that is also the time for our bonding despite my busy schedule.)

FGD-03 added,

"Matun-an nako ug samot ang akong mga anak kung aduna silay assignment ug mosamot ang amoang bonding."

(I can teach my children more with their assignments and our bonding together will become stronger.)

Moreover, FGD-06 asserted to share that,

"Naa mi panaghiusa sir sa balay. Mura pud mig mga maestra ug maestro magtudlo sa among mga anak."

(We have unity at home. We seemed to be like teachers teaching our children.)

\section{Coping Mechanisms of Parents in Dealing with the Challenges of Assignments of their Children}

People may experience sundry challenges in life. In a broader sense, this will help them improve themselves on how they will be able to cope with the challenges they may encounter. After scrutinizing the notions of the participants about their challenges in dealing with the assignments of their children, four (4) major themes were manifested such as: 1) understanding how to answer the lesson; 2) having balance and time management; 3) giving encouragement; and 4) having followups and rules.

Table 3 presents the major themes and core ideas on how the parents addressed the challenges they encountered.

Table 3

Major Themes and Core Ideas on the Coping Mechanisms of Parents in Dealing with the Challenges of Assignments of their Children

\begin{tabular}{|l|l|}
\hline \multicolumn{1}{|c|}{ Major Themes } & \multicolumn{1}{|c|}{ Core Ideas } \\
\hline & $\begin{array}{l}\text { She understands the situation of her children. } \\
\text { She always tries her best to help her children do the } \\
\text { homework. } \\
\text { She has focus with herself so that her children will do } \\
\text { the same. } \\
\text { She asks her children on how to answer the homework } \\
\text { and helps them. } \\
\text { Understanding How to } \\
\text { Answer the Lesson } \\
\text { making homework when nobody will. } \\
\text { She makes the assignment more understandable so that } \\
\text { it is easy for the children to understand. } \\
\text { She checks their books and notebooks on what to do. } \\
\text { She extends her patience just to always try her best to } \\
\text { give the right answer as much as she can give. }\end{array}$ \\
\hline
\end{tabular}




\begin{tabular}{|c|c|}
\hline $\begin{array}{l}\text { Having Balance and Time } \\
\text { Management }\end{array}$ & $\begin{array}{l}\text { Time management is very important. } \\
\text { She always tries spending time for her children. } \\
\text { She just spends some time for the students despite of } \\
\text { being busy. } \\
\text { She is trying to set her time helping each of her children. } \\
\text { She has always time for her children especially to their } \\
\text { studies. } \\
\text { She ensures to finish her works at home just to give time } \\
\text { with the assignments of her children. } \\
\text { She has a schedule every afternoon in doing their } \\
\text { homework. }\end{array}$ \\
\hline Giving Encouragement & $\begin{array}{l}\text { She gives her children money or a reward for them to be } \\
\text { motivated to answer their assignments. } \\
\text { She does her best to give encouragement to her children. } \\
\text { She encourages her children to study harder for their } \\
\text { dreams. } \\
\text { She gives her children full support just to help their } \\
\text { homework. } \\
\text { She encourages her children to study more and more. } \\
\text { She encourages her children to study especially in } \\
\text { reading to learn more. }\end{array}$ \\
\hline Having Follow-Ups and Rules & $\begin{array}{l}\text { She asks the child or his classmates or his classmates' } \\
\text { mom just to have follow-up. } \\
\text { She has her own rules to follow that the students should } \\
\text { obey. } \\
\text { She asks her children of what they have learned in } \\
\text { school so that the assignments will be answered } \\
\text { appropriately. } \\
\text { She has her own policy which is a homework or study } \\
\text { first. } \\
\text { She asks the children especially to the teacher just to } \\
\text { have some follow-ups. }\end{array}$ \\
\hline
\end{tabular}

\section{Understanding How to Answer the Lesson}

This theme contained about the challenges of parents in dealing with the assignments of their students. Their answers explained that understanding how to answer the lessons helps lessen the burdens of their children.

In line with this, IDI-01 stated,

"Sir, sa tinud-anay g'yud miskag dili lalim mag-atubang sa mga bata nako pero gipaningkamutan g'yud nako nga at least masabtan ug matabangan g'yud sila oi."

(Honestly, it is not easy helping and guiding the children, but I strived hard to understand and assist them.)

IDI-02 expressed, 
"Basta ako lang g'yud gipaningkamutan sir nga matabangan nako akong mga nak sa pagbuhat ug assignment. Tapos naga-pray pud ko nga tabangan ko sa ginoo nga masulbad nako pag-answer ang mga assignments sa akong mga anak.”

(I always try my best to help my children do their homework and I pray to God that He will guide and give me wisdom to solve their assignments.)

IDI-03, IDI-06, and IDI-07 shared their thoughts on how they coped with the challenges they encountered.

"Pukos lang jud ko sir para ang bata mo pokus pud sir." (IDI-03)

(I just have my focus with myself so that my children will do the same.)

"Mangutana ra pud ko sa akong mga anak unsaon pag answer sir tas tabangan nalang pud nako kung unsaon siya pag answer.” (IDI-06)

(All I do is to ask my children how to answer it then I just help them.)

"Isipon nalang nako na ug dili nako siya tabangan, kinsa paman diay ang mutabang sa akong mga anak para makakat-on?” (IDI-07)

(I always thought if I could not help them, who else would help them to learn?)

FGD-02 optimistically stated,

"Kayanon g'yud nako sir, kung puede ipasayon nako ug pagsabot ang lisod para sa ilaha."

(As much as possible, I will make their assignment more understandable so that it is easy for them to understand.)

FGD-06 shared,

"Mangutana lang g'yud ko sir. Usahay e-check pud nako sa libro ug mga notebooks kung unsay buhaton."

(I always ask and check their books and notebooks on what else to do.)

Further, FGD-07 revealed,

"Ang akong gibuhat lang sir no kay ang pagpailob g'yud tawn miskag naglisod ko labi na sa ilahang mga batasan sakong mga anak ug gipaningkamutan nako nga ma tama pud akong answer."

(What I am doing is to extend my patience even if I find it difficult especially in dealing with my children's attitudes. And I always try my best to give them the right answer.)

\section{Having Balance and Time Management}

Based on their responses to the question as to how to handle the challenges of parents in dealing with assignments of their children, hence, for some parents, having balance and time management emerged as a theme.

In connection to this, IDI-04 revealed her answer that,

"Time management lang g'yud sir ang pinaka importante tapos mangutana sa teacher kung gikinahanglan." 
(Time management is very important, and I will ask the teacher if needed.)

IDI-06 also shared,

"Pero usahay maggahin baya ko ug oras sa ila kay maluoy pud ko kung dili sila ka answer."

(I really spent time for my children because I pity them if they cannot answer their assignments.)

IDI-07 expressively stated that,

"Gigahinan lang g'yud nako ug time sir miskag sa ka busy sa mga trabahuon para naa g'yuy mahimo nga assignments."

(I just spend some time for them despite being busy just to help finish my children's assignments.)

FGD-01, FGD-03, and FGD-05 fairly shared their thoughts that,

"Naningkamot lang sir nga mabahin-bahin nako ang oras sakong mga anak nga matabangan sila." (FGD-01)

(I divided my time well and tried to set my time helping each of them.)

“Adunay oras lang g'gyud kanunay sa akong mga anak sir labaw na sa ilang pagtuon.” (FGD-03)

(There is always time for my children especially to their studies.)

"Ang akoa pud kay dali-on nako ang mga buluhaton sa panimalay labi na sa pagluto sa pagkaon sa gabie aron sayo makakaon ug moatubang na sa ilang homework sir.” (FGD-05)

(I will ensure to finish my works at home especially to cook dinner early so that they can eat early and focus with their assignments right away.)

Thus, FGD-07 exclaimed that,

"Magahin ko ug panahon lang g'yud sir mataghapon aron magtuod napud sila nga ting assinment na."

(There must be a schedule every afternoon in doing their homework so that they will develop it as a habit.)

\section{Giving Encouragement}

The next theme is about making someone hopes for the best. Hence, for some participants, giving encouragement emerged as one of the themes of the parents in handling certain circumstances especially in dealing with the assignments of their children.

In connection of this, IDI-01 revealed,

"Ang gibuhat lang g'yud nako sir no kay usahay tagaan nako sila ug kuwarta para ma motivate sila ug buhat sa ila assignments."

(I will give them money or a reward so that they will be motivated to answer their assignments.)

IDI-07 expressed, 
"Maningkamot lang ko sir nga ma answeran ilang assignments tas istoryahan lang nako sila nga magbuhat g'yud."

(I will do my best that I will be able to help their assignments and encourage them to really do their homework.)

Further, FGD-01 added her thought that,

"Nahimo siyag usa ka leksiyon nako sir sa kinabuhi sakong pamilya. Papaningkamuton nako sila sir oy nga magkugi sa ilang pag-eskuwela para sa ilang mga pangandoy sa kinabuhi sir."

(It serves as a lesson in our family and I encouraged them to study harder for their dreams in life.)

FGD-03 also expressed,

"Gitagaan lang g'yud nako ug suporta ang akong mga anak sir sa pagtabang sa ilang assignments."

(I give my children full support just to help their homework.)

FGD-04 added,

"Ma encourage sila nga magtoon pagmaayo."

(They will be encouraged to study more and more.)

FGD-07 stated,

"Mao nang gipaningkamutan nako nga pabasahon pabasahon sila para naa gyoy makat-unan, palangga kaayo nako na sila sir ay."

(That is why I encourage my children to study especially in reading in order to learn more because I love them very much.)

\section{Having Follow-Ups and Rules}

The responses expressed the ways of the participants in helping children for the completion of homework. Hence, having follow-ups and rules emerged as one of the themes in the realization of the parents in dealing with the assignments of their children.

IDI-04 stated,

"Mangutana ko sa bata or di kaya sa iyang classmates or sa mama sa iyang classmates kung unsay assignments para makabuhat pud akong anak kung maglibog ko usahay unsay gipa assignment."

(I will ask the child or his classmates or his classmates' mom on what are the assignments so I can help my child if it is sometimes confusing to answer.)

FGD-01 exclaimed her thoughts,

"Ug naa jud koy pamalaod nga unahon ug buhat ang mga assigments nga gihatag sa teacher before magdula o bahala na sila sa ilang buhaton basta mahuman lang sila sa ilang ginggbuhaton."

(I have my own rules to follow that they should do their homework first before playing or doing something on their own.)

FGD-02 added, 
"Mangutana ko sa ilaha kung unsa ila gibuhat sa eskuwelahan aron ma answeran ug tarong ang assignments.”

(I will ask them on what they have learned in school so that the assignments will be answered appropriately.)

FGD-05 shared her ways,

"Akong ginabuhat pud sir kay magahatag ko ug palisiya na homework o study first usa motan-aw ug salida sa TV.”

(What I did is to have my own policy which is a homework or study first before watching a television.)

Moreover, FGD-06 firmly answered that,

“Mangutana g'gyud ko sir sa ilaha ug mahimo nako mangutana ko sa teacher mismo kung unsay pagabuhaton."

(I will ask them especially to the teacher on their tasks and homework to have some follow-ups.)

\section{Parents' Suggestions Regarding the No-Homework Policy}

After analyzing the perspectives of the participants about their suggestions as parents regarding to the no-homework policy, four (4) emergent themes were revealed: 1) parents should always be responsible and helpful to their children; 2) parents should have time management and balance; 3) teachers should give appropriate, simple and uncostly homework; and 4) teachers should give homework to students for continued learning.

Table 4 shows the major themes and core ideas about the suggestions of parents on the nohomework policy that can be shared to others.

Table 4

Major Themes and Core Ideas on the Suggestions of Parents on No-Homework Policy

\begin{tabular}{|l|l|}
\hline \multicolumn{1}{|c|}{ Major Themes } & \multicolumn{1}{c|}{ Core Ideas } \\
\hline & $\begin{array}{l}\text { Parents should be responsible in helping children when } \\
\text { they ask for a favor. } \\
\text { Parents must treat children with love, care, and extend } \\
\text { their patience to help finish the students' assignments. } \\
\text { Parents should be vigorous to follow up their children. } \\
\text { Parents should be responsible for the lives of their } \\
\text { children. } \\
\text { Parents are accountable to their children in teaching } \\
\text { good lessons. } \\
\text { Parents Should Always be } \\
\text { their Children } \\
\text { for them to grow with wisdom and knowledge. }\end{array}$ \\
\end{tabular}




\begin{tabular}{|c|c|}
\hline $\begin{array}{l}\text { Parents Should have Time } \\
\text { Management and Balance }\end{array}$ & $\begin{array}{l}\text { Parents should give enough time for their children so } \\
\text { that they will be able to complete their assignments. } \\
\text { Parents should spend time with their children to guide } \\
\text { their study. } \\
\text { Parents should give time for their children to learn. } \\
\text { Just give time helping with the assignments of the } \\
\text { children and do follow-ups on what they have learned in } \\
\text { school. } \\
\text { Parents should give time to the students at least } 10 \\
\text { minutes for checking their notes. } \\
\text { Parents should set their minds and hearts that time } \\
\text { management is important. }\end{array}$ \\
\hline $\begin{array}{l}\text { Teachers Should Give } \\
\text { Appropriate, Simple and } \\
\text { Uncostly Homework }\end{array}$ & $\begin{array}{l}\text { The teacher should not give difficult assignments at all. } \\
\text { Assignments should be appropriate to the lesson. } \\
\text { Assignments should only be accessible to students. } \\
\text { Assignments should be uncostly and will not involve } \\
\text { money. } \\
\text { Teachers will only give simple and not too many } \\
\text { assignments. } \\
\text { Assignments should only be few so that students will } \\
\text { have time for themselves. }\end{array}$ \\
\hline $\begin{array}{l}\text { Teachers Should Give } \\
\text { Homework to Students for } \\
\text { Continued Learning }\end{array}$ & $\begin{array}{l}\text { She realized that a child is willing to study if there is } \\
\text { homework. } \\
\text { Homework helps children learn better. } \\
\text { Teachers should continue giving assignments for the } \\
\text { study habit of children. } \\
\text { The no-homework policy will bring no good to the } \\
\text { children. } \\
\text { Teachers should continue giving assignments and should } \\
\text { fight against the no-homework policy. }\end{array}$ \\
\hline
\end{tabular}

\section{Parents Should Always be Responsible and Helpful to their Children}

This theme contained about the suggestions of the participants that parents should always be responsible and helpful to their children.

IDI-01 revealed,

"Grabe g'yud ako nasinati samtang nagatabang sa ilang buluhaton. Pero hagit nato ni sa mga ginikanan nga maging responsable pud ta sa ila. Tabangan g'yud nato sila labi nag mangayo silag tabang nato."

(I have been through a lot of trials while helping with their homework. But it is a challenge for us parents to be responsible. We should help them when they ask for a favor.)

IDI-02 expressed, 
"Ang akong masulti kay dili gyud mag stress stress ug tabang sa mga bata nato. Dapat buhaton nato siya nga naay gugma, pag-care sa ilaha ug taas ato pasensiya para mahuman nato siya nga maayo."

(What I can say is do not stress yourselves in helping our children and we must treat them with love and care and extend our patience so that we can finish it well.)

IDI-04 shared her thought that,

"Ang no-homework policy isip usa ka ginikanan kinahanglan nato ang modasigon na pag follow up sa atong mga anak."

(We should be vigorous to follow up our children's progress or assignments.)

FGD-01 suggested,

"Importanteng magpakabana g'yud ta sa kinabuhi sa atong mga anak isip usa ka ginikanan."

(It is important that we should be responsible for the lives of our children as parent to them.)

FGD-03 stated that,

“Isip ginikanan, ato g'yud nang tulubagon ug tun-an ang atong mga anak sa maayong pagtulun-an bisan naa may klase o wala."

(As parents, we are accountable to our children in teaching good lessons whether they are in the classroom or not.)

Further, FGD-04 expressed that,

"Magkugi ta ug tudlo sa atong mga anak aron sila mutubo nga adunay kahibalo."

(Be responsible in helping our children so that they will grow with wisdom and knowledge.)

\section{Parents Should have Time Management and Balance}

The next theme is about the suggestions of participants of having time management and balance. It is marked as the third theme in the responses of the participants.

IDI-04 stated that,

"Dapat tagaan g'yud sila ug panahon para mahuman ang assignments ug dali."

(We should give enough time for our children so that they will be able to complete their assignments.)

IDI-05 shared,

"Gusto nako ipaambit sa ilaha sir nga paghatag lang g'yud ug panahon sa inyong mga anak aron sa ingon mapasunod nato sila ug ma guide sa ilang pag-eskuwela."

(I just want to suggest that spending time with our children helps us to guide them in their studies.)

FGD-02 narrated,

"Dili man jud malikayan nga daghan man g'yud ta ug buluhaton sa balay hatagan pud nato ug oras nga matun-an atong mga anak." 
(It is undeniable that we have a lot of works at home, but we should spend time for our children to learn.)

FGD-03 expressed,

(Just give time helping with their assignments and do follow-ups on what they have learned in school.)

Moreover, FGD-06 and FGD-07 suggested,

"Di man guro bug-at mahatag ta ug maski 10 minutes para para lantawon ang mga sinulat sa atong mga anak kay madasig pud na sila muuli magbitbit sa ilaha scores.” (FGD-06)

(Just give at least 10 minutes for checking the notes for our children because they will be excited to go home with their amazing scores.)

"Nga kanang kinahanglan g'yud parents e-set sa atong hunahuna ug kasingkasing nga importante ang time management aron sa ingon dili maglisod sa panahon." (FGD-07)

(It is required that parents should set their minds and hearts that time management is important so as not to waste time.)

Teachers Should Give Appropriate, Simple, and Uncostly Homework

The responses of the participants revealed the suggestions of parents to the teachers with regard to the giving of assignments it should be appropriate, simple, and inexpensive.

IDI-01 expressed,

“Ang ako lang masulti nga muhatag lang g'yud ug assignments ang mga teachers nga dile pud kaayo lisod aron kami nga ginikanan matabangan namo sila. Ug unta ang mga teachers andam pud mutabang sa among mga anak."

(All I can say is that teachers should not give difficult assignments so that we will be able to help them. And the teachers should also willing to help our children.)

ID-04 suggested that,

"Dapat ang mga assignments haom gyud sa ilang leksiyon."

(The assignments should be appropriate to their lesson.)

IDI-07 also added,

"Unta ang mga teacher kung magpa homework dapat dili lisod ug dali ra pangitaon ang mga kailanganon sa mga bata sa komunidad."

(If there are materials needed, they should only be accessible or found in our place.)

Further, FGD-01 inferred,

"Basta ang assignments lang g'yud sir dili lang g'yud maggasto-gasto."

(As long as the assignments are uncostly and will not spend money.)

FGD-04 and FGD-06 optimistically expressed, 
"Unta ang mga teachers kung maghatag ug assignments kanang gamay ra unta ug simple lang kay para dili pud sila maglisod ug dali ra sila makasabot ug dili pud mi ginikan maglisod ug tabang sa ila sir." (FGD-04)

(I hope also teachers will only give simple and not too many assignments so that we will be able to understand easily and we will not find it hard to help them.)

"Unta sir di pud maghatag ug assignments nga daghan kaayo kay para ang mga bata naa pay time mabilin para sa ilang sarili.” (FGD-06)

(I hope the assignments are only few so that they will have time for themselves.)

\section{Teachers Should Give Homework to Students for Continued Learning}

This theme contained about the suggestions of parents not to pursue no-homework policy for continued learning. It emerged as the first theme in the responses of the participants.

In line with this, IDI-03 expressed that,

"Na realize nako sir no nga pursigido mag study ang bata kung naay assignments."

(I realized that a child is willing to study if there is homework.)

Besides, FGD-01 shared her thoughts that,

"Unta dili malipay ang mga ginikanan sir nga mawala ang homework sa panimalay kay para raman pud ni makabalo sa atong mga bata ug makatabang man kini aron makamao pud ang atong mga anak."

(Parents should not be happy about the elimination of homework because homework helps our children learn better.)

FGD-03 also suggested,

"Para usab sa mga magtutudlo ang paghatag ug assignments ipadayon kini para pud sa study habit sa among mga nak pag-abot sa balay."

(To all the teachers, they should continue giving assignments for the students to develop study habit at home.)

Further, FGD-04 narrated,

"Isip ginikanan dili kita angay nga mo ok ta sakini nga balaod kay dili ni makatabang sa atong mga anak ug makaapekto kini sa ilang unta nga matun-an.”

(As a parent, having this policy will bring no good to our children. We should not agree with this for it will affect the learning ability of our children.)

FGD-07 inferred,

"Ang akong ma rekomendar sa mga magtutudlo sir nga padayon ang paghatag ug assignments nga kanang dili pud kaayo lisod. Ug ipaglaban unta nila nga dili musugot sa no-homework policy. Na sir unsaon nalang among mga anak ineg abot sa panahon."

(My recommendation for teachers is to continue giving assignments that are not too difficult. And they should fight against the no-homework policy for the future of our children.) 


\section{DISCUSSIONS}

The purpose of this qualitative research study was to explore and understand the lived experiences and different perceptions of parents on No-Homework Policy. The findings from the previous chapter provided the researcher with essential information obtaining the perspectives of each participant relative to the topic. All participants partook in interviews in which open-ended questions were employed. The viewpoints of parent-participants highlighted their insights, experiences, opinions, and concerns. The emergent themes that marked from data analysis may provide important insights for the purpose of giving thoughts and awareness to the general public especially to the parents in Nangan Elementary School, Nnangan, Governor Generoso, Davao Oriental who are the main concerns of this current study.

\section{Parents' Perceptions on No-Homework Policy}

The parents who were chosen as the participants shared their perspectives as to how the possibilities of No-Homework policy may impact to students. There were four (4) major themes emerged namely: 1) no-homework policy can be optional; 2) no-homework policy is unfavorable and unhelpful to students; 3) no-homework policy causes students become irresponsible; and 4) nohomework policy causes less learning among students.

\section{No-Homework Policy can be Optional}

Everything has its own way of purpose. A purpose which can truly help an individual foster, grow, and fully developed. Parents would like to provide something which is vital to their children. According to the participants of my study, they wanted homework for their children for as long as it is optional. Parents believed that homework gives essential benefits provided that the students should also be given time for themselves. Additionally, some parents would like to express the thoughts of weighing the time of having homework and the time of having not. So, no-homework also can be optional.

Further, Marcum (2018) cited on his study, parents believe that teachers are trained to make appropriate educational decisions for their child and that the relationship between parents and teachers should be reciprocal in regard to what works best for each child. The parents also believe that teachers also have considerations the amount of homework given to their children.

Additionally, Shumaker (2016) stated the statement of homework research guru Harris Cooper, of Duke University, there is no evidence that any amount of homework improves the academic performance of elementary students. Thus Shumaker (2016) stressed that homework has benefits, but its benefits are age dependent. He also added that what works better than traditional homework at the elementary level is simply reading at home. This can mean parents reading aloud to children as well as children reading. The key is to make sure it is joyous said by Shumaker. However, any other projects that come home should be optional and occasional. If the assignment does not promote greater love of school and interest in learning, then it has no place in elementary school-aged child's day (Shumaker, 2016).

\section{No-Homework Policy is Unfavorable and Unhelpful to Students}

No-Homework Policy is the most controversial issue today. Parents have fairly given their insights about what no-homework policy may bring to the lives of students if it will be practiced. Based on the responses, majority of the participants felt disappointed if the policy will be pushed by the higher authorities of education. The participants expressed their thoughts that the students' 
learning progress may be strongly affected if and only if homework will be banned. Thus, students will only do strolling around and playing games with their cellular phones and that would make parents unfavorable and helpful in the faces of their children. On the other hand, parents wanted a transparency of homework to improve the academic achievement of their children.

Besides, some participants had mixed reactions about the proposal to ban all assignments to be done at home or in their own time. They would think of the possibilities that no-homework policy may bring into the existence or portal of children's education.

Further, Elicay (2019) stated that many still agree that kids need homework, but the amount should also be taken into consideration. Elicay shared the various perceptions of the proposed bill. She also ran a poll on the Smart Parenting about the Filipino parents think of the no-homework policy and out of 2,000 votes, $80 \%$ believe that students still need homework, while $20 \%$ think children can do without it.

However, Lyons (2018) as cited by an educator Joseph Adegboyega-Edun stated that homework develops important skills. He added that students who do their homework, understand the subject, and earn better grades are more successful in school because homework compels them to review and apply what they have learned. However, when homework is banned, students then develop poor study and poor test preparation habits, which will hurt their success in college. He also stressed that a homework bans means more time on social media and computer games.

\section{No-Homework Policy Causes Students to Become Irresponsible}

Based on the answers of the participants, parents would like students to be responsible of one's own learning. If no-homework policy will become a law, it would possibly call students become slothful. Slothful in a way that students will become irresponsible and have no time for studies because they are busy with their gadgets which are now considered as the working leisure of children. Additionally, that will make parents worry if homework discontinues or stops. That is why parents would like to have homework with their children for them to become responsible with their studies.

Further, Sharp et al. (2001) as cited by Audu (2016) stated that learners generally have a positive attitude to homework, and they feel it is important in helping them to do well at school. Learners prefer interesting, challenging, and varied tasks that are clearly defined and have adequate deadlines to tedious, boring and busy-work homework (Sharp et al., 2001).

Moreover, Audu (2016) stated that Vaughn and her research colleagues (Protheroe, 2009) reported that learners find it helpful when teachers assign homework towards the beginning of the class; explain how to do the homework, including providing examples and writing directions on the chalkboard; give learners time to start the homework in class, checking for understanding and providing assistance before the end of the class period; explicitly relate the homework to class work; and permit learners to work together on homework in class. These would make learners more responsible.

\section{No-Homework Policy Causes Less Learning Among Students}

The learning of one's child is the prime purpose of the parents. However, parents are eager to provide all the desires of the children just for their welfare. Conversely, parents caught the attention of the issue as regards to the elimination of homework, thus different perceptions were revealed. As my participants expressed their viewpoints concerning the issue, they were poked about some things might happen if the no-homework policy will be exercised in schools. They were 
worried about the learning progress of their children. Based on the answers of my participants, if homework will be banned in schools the students will continue to learn nothing and the interest of their children might lose.

Furthermore, Peralta (2019) stressed that prohibiting schools from assigning homework to students may have detrimental effects on a child's learning capabilities, a child psychologist claimed, contrary to the argument of education officials. However, Jhon Carandang from the The Masters Psychological Services said removing homework from a student's study practice is dangerous. He said that students must review what they learned from school to hone their minds. Carandag added that it will be dangerous for the child to have no-homework because it would lead to a poor study habit.

\section{Parents' Experiences in Dealing with the Assignments of their Students}

With the personal experiences of my participants in dealing with the assignments of their students, they were able to understand the realities of life. From the results of the study, there were five (5) major themes were manifested such as: 1) having difficulties in answering homework; 2) being able to help children; 3) having fun while doing the assignment; 4) being unable to finish work or chores; and 5) bonding opportunity.

\section{Having Difficulties in Answering Homework}

Every single person has difficulties in life. The participants also revealed their difficulties while having assignments with their children such as: having no references to answer the homework, the assignments are not clear on how to answer, and students did not copy the instructions of the assignments. Furthermore, most parents find homework difficult to answer when they do not actually know about the assignments at all.

However, homework frustration is common for parents. Normally understanding parents who identify the importance of being sensitive to the needs of their children find it difficult to respond with the appropriate level of sensitivity when it comes to 28 homework problems (Cunha et al., 2015). While completing homework, all students and parents would benefit from a commitment to exhibiting positive emotions (Katz et al., 2012).

\section{Being Able to Help Children}

Based on the responses of parents, they also had the best experiences while having the assignments of their children. That is to be able to help children finish their homework. Participants believed that homework is the avenue of helping children learn more and an opportunity to follow up of what they have learned in school. More so, parents were blissful seeing the happiness on the faces of their children after helping them complete the assignments.

Additionally, according to Fan (2013) as cited by Cunha et al. (2015) found that the majority of parents with elementary-age students believe they are fully capable of assisting their children with homework completion. Moreover, Phares (2017) stressed that elementary school teachers assign homework that requires family involvement and understand that such assistance is necessary for completion. Parents report that assisting their children with homework improves their relationships with their children (Bennett \& Kalish, 2006 as cited by Audu, 2016).

\section{Having Fun While Doing the Assignment}


Assisting their children with homework improves their relationships with their children. Parents also shared that homework provides something new and different experiences. Some said that they were having fun helping their children to learn more. Also, while having assignments they were also learning. They just enjoyed the moment together with their children while doing such.

Further, Silinskas et al. (2015) remind us that achieving parental involvement is not without challenge, since homework can be an emotionally charged event for all concerned. Engaging in homework can produce a range of emotional responses and parents need to be aware of the dangers of the potentially vicious circle of increased negative emotion and the detrimental effect of over involvement (Silinskas, 2015).

However, the type of parental affect is, therefore, significant. Positive affect, defined as the "enjoyable, loving, and supportive interaction" that parents can experience in homework situations can enhance the child's feelings of relatedness and thereby promote their learning motivation (Silinskas, 2015).

\section{Being Unable to Finish Work or Chores}

One of the themes emerged in the experiences of parents in dealing with the assignments of children is unable to finish work or chores. Most of the participants have the same experiences. The time for making their household chores was sacrificed especially when the assignments were too many. So, parents will not be able to do some stuff at home.

Moreover, the issue of time is crucial in the practice of homework. Learners complain that homework takes away much of their leisure time; parents need time to do their work; and teachers have to set, mark and give feedback, which requires time (Cooper, 2007). Doing homework is disadvantageous to less privileged children and parents as they need time to help their parents in their businesses or with household chores, resulting in their inability to complete their homework.

Further, Cooper (2007) as cited by Audu (2016) stated that not all parents are entirely positive about the purposes of homework, regardless of whether there are disputes within the family about its completion. Parents sometimes express frustration because they do not understand the homework that learners bring home from school. They sometimes complain about the length, standard and clarity of the homework. As a result, homework becomes the source of complaint and friction between home and school. As educators, parents, and learners view home and school as adversaries when it comes to the issue of homework.

\section{Bonding Opportunity}

Homework can facilitate the bonding opportunity among parents and children. Moreover, most parents believed that homework is a way of elating the relationship between them. According to their responses, the participants would be very happy if they were having their homework. Further, they will be able to teach their children more with the assignments thus the opportunity of bonding will become stronger together.

Additionally, Marcum (2018) cited that some families believe that time spent on homework takes away from quality family time whereas other parents acknowledge that homework brings them together. In fact, homework is a widely supported practice.

Further, Audu (2016) stressed that parents also have different views about homework and get involved in their children's homework in diverse ways. They feel more positive about their abilities to help their children in primary grades and rate teachers as better teachers, while learners improve their attitudes and achievements (Epstein, 2001). 
Besides, parents want teachers to set homework, because their regular involvement in the completion of homework increases their interactions with children at home. Coutts (2004) maintains that in general, parents see homework's potential benefit largely as achievement-related; it leads to increased success on class work and fosters attitudes and habits that lead to successful future learning.

\section{Coping Mechanisms of Parents in Dealing with the Challenges of Assignments of their Children}

The participants were asked on how they cope with the challenges they encountered in dealing with the assignments of their children. There were four (4) major themes manifested such as: 1) understanding how to answer the lesson; 2) having balance and time management; 3) giving encouragement; and 4) having follow-ups and rules.

\section{Understanding How to Answer the Lesson}

Undeniably, we have our own challenges to face that we cannot resist but rather embrace. Parents really have struggles for the completion of homework. Thus, parents would be able to conceive the purposes why homework exists in the lives of students. Based on the responses, if parents are having hard time in answering the assignments, they would try to find some ways and means just to help their children. The parents were able to understand the situation and help children for one's own welfare.

Further, Fox (2016) studied six North Carolina families that resided in low-income housing to determine how homework was perceived by these families. Mothers provided data for the study. These parents found that homework was necessary to track their child's progress, help them to understand school curriculum, provided learning routines for their children, and was a valuable opportunity for siblings to work together.

Moreover, all of the participants expressed fear of reaching a point where they would be unable to adequately assist their students with homework completion. One final important aspect to the research was the desire from parents to see feedback on their child's work. Failing to provide feedback was viewed in a negative light (Fox, 2016).

\section{Having Balance and Time Management}

In having deep conversation of the participants, they would come to infer that parents should have balance and time management. Balance and time management were stressed by most of the participants so that the parents will be able to finish homework. Moreover, having balance and managing time in every situation makes parents complete homework at ease.

Furthermore, Stoeger and Ziegler (2008) as cited by Marcum (2018), studied the impact that five weeks of weekly training in self-regulation and self-efficacy would have on fourth grade students during homework activities. These students displayed improved self-efficacy, time management skills, and a greater proficiency at reflecting accurately on their own learning. Studentparticipants also experienced increased homework completion rates during the study that remained constant while their counterparts saw a decrease in homework completion rates throughout the entirety of the study.

\section{Giving Encouragement}


Encouragement is an activity of encouraging someone to develop their utmost potential. It is also an action of giving someone support, confidence, and hope. That is the vision of those participants who wanted to encourage children in making their studies meaningful and purposeful. Some participants believed that a person who has full support and full of giving encouragement from the parents will be able to succeed in life.

Further, Moe et al. (2018) revealed the result of their study which involved 122 parents and their children, showed that the higher the parental autonomous motivation, the more their children perceived them as autonomy supportive while scaffolding for motivation, and hence developed autonomous motivation, self-efficacy, and engagement in homework. However, the parents are helping their children develop less negative, and potentially also more positive attitude towards homework, through autonomy support as a scaffold for motivation.

As studied by Orkin et al. (2017), the researchers found out that parental involvement for the child's homework completion resulted to helpless behaviors such as having a feeling of anger or annoyance caused by parents and act of avoiding in completing tasks given by a teacher. Otherwise, as posited by the researchers that involving parents to homework completion could not cause to disruptions, but it would rather lead to helping and assisting their children to stimulate in learning.

\section{Having Follow-ups and Rules}

One of the coping mechanisms of parents in dealing with the assignments of their children is having follow-ups and rules. Parents believed that through these ways, they will be able to assist one's own learning and can ensure the learning progress of a child. Additionally, parents would make sure if the students have really learned the lesson well or would still need an improvement. Parental involvement is necessary for student success (Cunha et al., 2015). The idea of parental involvement takes as a solution in an education system in helping educators to positively result to scholastic achievements of one's child.

However, as cited by McCormick (2014) parental involvement in the educational experience has demonstrated the essential element to achieve quality education and will also result to educational future learning of their children. Additionally, parents have essential roles in lives of their children to ensure follow-ups of one's learning progress.

\section{Parents' Suggestions Regarding the No-Homework Policy}

The participants of this current study were asked about the suggestions and realizations on no-homework policy that can be shared to others. The four (4) emergent themes were revealed namely: 1) parents should always be responsible and helpful to their children; 2) parents should have time management and balance; 3) teachers should give appropriate, simple and uncostly homework; and 4) teachers should give homework to students for continued learning.

\section{Parents Should Always be Responsible and Helpful to their Children}

Regular homework is a necessary part of learning because it accelerates the pace of knowledge acquisition. Thus, parents are accountable to the learning progress of a child and so they should be responsible and helpful to their children. The participants suggested that parents should also help students anytime when they ask for a favor and support them throughout their studies.

Additionally, parent participation in the schools and positive relationships with teachers are essential to student success. This means that homework transparency is crucial. Confident, well- 
spoken, and highly informed parents are more likely to participate in their child's school (LaRocque et al., 2011 as cited by Marcum, 2018).

Moreover, Audu (2016) cited the study that another major finding is a lack of parental support. School leadership at the levels of principal, HoDs, and teachers complained that parents do not support their children in the practice of homework. They emphasized the fact that most learners are taken care by their grandparents, some parents are illiterate, and some learners are orphans.

Learners with these problems have no one to support them to complete their homework; hence non-completion of homework. For learners to benefit, they have to complete their homework so that teachers can use the feedback to reflect on their teaching and make modifications where necessary to enhance learning. If learners fail to do homework, then teachers will have no information to assess learners' progress for the purpose of promoting learning. If leaders at the level of parents are unable to support their children, then the practice of homework may not be effective, thus, it may not contribute to learning and learner outcomes. Further, Wilder (2017) stressed that parents believe that their children are more successful in Mathematics at the elementary school level when the relationship between parents and the school is effective.

\section{Parents Should Have Time Management and Balance}

A concern that parents have about homework for their child is the length of time it takes their child to complete homework. Based on the responses of the participants, parents would like to suggest of having time management and balance in dealing with the assignments of a child. The quality time of parents will help children to be able to complete homework thoroughly.

Further, the amount of time a student spends on homework is not as important as actually taking the time to complete assigned homework (Maltese et al., 2012 as cited by Marcum., 2018). Moreover, Cooper (2015) stressed that the NEA's "ten-minute rule" with a daily limit of 10 minutes of assignment per grade level for elementary pupils were generally adhered by most educators and school divisions. Also, the teachers assign homework to keep parents informed and try to adhere to the 10-minute rule (Gallo, 2015).

\section{Teachers Should Give Appropriate, Simple, and Uncostly Homework}

Giving appropriate, simple, and uncostly homework were the recommendations of parents that teachers must consider and realize. Additionally, parents would like to recommend assignments that are not too difficult to answer so that they will be able to answer it well. The assignments also should be accessible or found to their places.

In line with this, Valle et al. (2016) posited that the increasing homework workloads do not necessarily equate to academic success nor the amount of time that students spend on homework each night. Further, appropriateness of homework is highly needed to ensure better learning of the students.

In the broader sense, Palacios (2017) revealed that the data also indicated that a significant amount of anxiety did not exist for students completing less than an hour of homework each night or students that reported completing one to three hours per night. However, students completing over three hours of homework per night experienced high stress levels. So, it is much better that the assignments given by the teachers should be simple so that the parents are not having a hard time to complete the homework assignments. 
Furthermore, despite belonging to the group of students benefiting most from homework, high school students who exceed more than three hours of homework per night are more likely to experience academic stress and physical health problems (Galloway et al., 2013).

Moreover, Sieborger and Macintosh (1998) as cited by Audu (2016) that assessment is said to be successful when learners regard it as fair which refers to the fairness of assessment as its validity and reliability. For them, validity is the extent to which the assessment measures what it is purported to measure, while reliability refers to the consistency of assessment to always give the same result under any circumstances. Learners can only account for what they have learned and in the way in which they have learned it, therefore, assessment should then test what is learned. The appropriate use of assessment procedures helps children to learn well and taking all assessment decisions as a whole directs and alters children's learning.

\section{Teachers Should Give Homework to Students for Continued Learning}

Based on the responses of the participants, parents would like homework to be evident to students for the continuity of learning. Some parents expressed their thoughts that the teachers should continue giving assignments to the students for the study habit of their children. Homework implies that children will be more responsible to their studies because they will be interested to complete the homework assignments. In addition, parents would like No-Homework Policy not to pursue for one's continued learning.

Further, proponents reason as having an appropriate homework task, it will aid learners to develop skills academically that result to improve scholastic achievement. Homework has positive influence as to make learners improve their study skills, be responsible on their own learning, and positively develop qualities toward learning (Cooper et al., 2006, cited by Snead \& Burris, 2016).

Besides, educators who entrusted daily homework assignments are higher in teacher effectiveness and especially valued by students rather than those with teachers who assigned nohomework at all. Homework assignments more likely influence the study abilities of the students and make their own learning responsibly (Eren \& Henderson, 2007; Cooper \& Valentine, 2001; Xu, 2007 as cited by Snead \& Burris, 2016).

\section{CONCLUSIONS}

The investigation on the perceptions of elementary school parents highlighted the significance and the necessity of the study. The result of this study would hopefully be determined and utilized in shaping the lives of the students to be the best version of themselves.

In-depth interview and focus group discussion were utilized in gathering the lived experiences and perspectives of the participants in the study. I used the transcript of their responses as the primary source of data. The challenge was to convince the participants to express their insights and opinions about the study. I am very much blessed and grateful that the participants gave their full cooperation and honesty in sharing their experiences and thoughts during the interview.

As a researcher, I truly experienced a lot of struggles just to obtain rich information of my participants. I took all the indispensable measures to ensure this research becomes a meaningful and purposeful one. Verily, it has become a truism that research requires much time, attention, and efforts to ultimately achieve the best resource in my study.

Looking into considerations of my study, parents would like to have a desirable learning improvement of their children. So, the learning of the students must be taken into account. Ergo, the 
Department of Education should be responsible in making innovations for the sake of the students' learning progress.

These innovations are the avenues of all students to certainly mold them become better learners and the channel used to help learners showcase to their utmost potential, and also keep students be organized, focused, and active in and outside the classroom morally and academically. I greatly believe that schooling may be facile, may be strenuous. Some easily breezed their thoroughfare, some struggled. Whichever lane the students may pace in, they still end up in learning.

\section{REFERENCES}

Audu, J. U. (2016). An Exploration of School Leadership Conceptualisations of Homework: Practices, Affordances and Constraints

Braun, V., \& Clarke, V. (2006). Using thematic analysis in psychology. Qualitative Research in Psychology, 3:2, 77101.

Creswell, J. W. (2007). Qualitative inquiry and research design (2nd ed.). Sage Publications, Inc.

Creswell, J. W. (2013). Research Design: Qalitative, Quantitative, And Mix Method Approaches. Sage Publishing Inc.

Cunha, J., Rosário, P., Macedo, L., Nunes, A., Fuentes, S., Pinto, R., Suarez, N. (2015) Parents' conceptions of their homework involvement in elementary school Psicothema, vol. 27, núm. 2, abril-junio, 2015, pp. 159-165 http://www.redalyc.org/articulo.oa?id=72737093001

DepEd Memorandum No. 392, series 2010. Statement on the No-Homework Policy Bills https://www.deped.gov.ph/2019/08/28/statement-on-the-no-homework-policy-bills

Epstein, J., \& Van Voorhis, F. (2012). The changing debate from assigning homework to designing homework. Chp. 24. In Sebastian Suggate and Elaine Reese (Eds.) Contemporary Debates in Childhood Education and Development (pp. 263-274).

Fan, H., Xu, J., Cai, Z., He, J., \& Fan, X. (2017). Homework and students' achievement in math and science: A 30-year meta-analysis, 1986-2015. Educational Research Review, 20, 35-54. http://dx.doi.org/10.1016/j.edurev.2016.11.003.

Fox, K.R. (2016). Homework as a family literacy practice: What counts as best practices for children deemed as high risk for academic failure due to socioeconomic status. SchoolCommunity Journal, 26(2), 215-236. Retrieved September 10, 2017,fromhttp://files.eric.ed.gov/fulltext/EJ1124009.pdf

Gall, M., Gall, J., \& Borg, W. (2007). Educational research: An introduction. (8th ed.). Pearson Education, Inc.

Gallo, R. S. (2015). Listen to the teacher! An exploration of the teacher's voice regarding homework. ProQuest Dissertations \& Theses Global. https://searchproquestcom.iris.etsu.edu:3443/docview/1680593785/

Galloway, M., Conner, J., \& Pope, D. (2013). Nonacademic effects of homework in privileged, high-performing high schools. The Journal of Experimental Education 81(4). http://dx.doi.org/10.1080/00220973.2012.745469

Katz, I., Buzukashvili, T., \& Feingold, L. (2012). Homework stress: Construct validation of a measure. The Journal of Experimental Education, 80(4), 405-421. http://selfdeterminationtheory.org/SDT/documents/2012_KatzEtAl_JOEE.pdf

Lyons, J. (2018). 6 Educators Share Their Perspectives on Homework Bans https://study.com/blog/6-educators-sharetheir-perspectives-on-homework-bans.html

Marcum, J. (2018). "Parent and Teacher Perceptions of Elementary School Homework". Electronic Theses and Dissertations. Paper 3377. https://dc.etsu.edu/etd/3377 
McCormick, R. A. (2014). The Influence of Homework on the Educational Experiences from Low Socio-Economic Backgrounds: A Phenomenological Study

Moe, A., katz, I., \& Alesi, M. (2018). Scaffolding for Motivation by Parents, and Child Homework Motivations and Emotions: Effects of a Training Programme https://doi.org/10.1111/bjep.12216

Nuñez, J.C., Suarez, N., Cerezo, R., Gonzalez-Pienda, J., Rosario, P., Mourão, R., \& Valle, A. (2015). Homework and academic achievement across Spanish compulsory education. Educational Psychology, 35(6):726-746. https://dx.doi.org/10.1080/01443410.2013.817537

Nuñez, J.C., Suarez, N., Rosario, P., Vallejo, G., Valle, A., \& Epstein, J.L. (2015). Relationships between perceived parental involvement in homework, student homework behaviors, and academic achievement: Differences among elementary, junior high, and high school students. Metacognition and Learning, 10(3), 375-406. doi:10.1007/s11409-015-9135-5.

Orkin, M., May, S., \& Wolf, M. (2017). How Parental Support During Homework Contributes to Helpless Behaviors Among Struggling Readers, https://ase.tufts.edu/crlr/documents/2017howParentalSupportDuringHomework.pdf

Palinkas, L. A., Horwitz, S. M., Green, C. A., Wisdom, J. P., Duan, N., \& Hoagwood, K. (2015). Purposeful sampling for qualitative data collection and analysis in mixed method implementation research. Administration and Policy in Mental Health and Mental Health Services Research, 42(5), 533-544. https://www.ncbi.nlm.nih.gov/pmc/articles/PMC4012002/

Paris, J. (2019). DePed Supports Proposed No Homework Policy https://www.rappler.com/nation/238795-depedsupports-proposed-no-homework-policy

Patton, M.Q. (2002). Qualitative research \& evaluation methods (3rd edition). Sage Publishers.

Peralta, J. (2019). No Homework to Lead to Poor Study Habit https:// no-homework-policy-psychologistdeped.html4?fbclid=IwAR2BCr9ps8kblWmqRs4yjmwf

Pfeiffer, V. (2018). Homework policy review: A case study of a public school in the Western Cape Province South African Journal of Education, Volume 38, Number 1, February 20181 Art. \# 1462, 10 pages, https://doi.org/10.15700/saje.v38n1a1462

Phares, T. (2017). A purposeful understanding of homework. ProQuest Dissertations \& ThesesGlobal.https://searchproquestcom.iris.etsu.edu:3443/pqdtglobal/docview/1898703416/DDC8155CE15 D4CEAPQ/1?accountid=10771

Protheroe, N. (2009). Good homework policy. Principal, September/October Psychologist, 36(3), 155-165. http://dx.doi.org/10.1207/S15326985EP3603_2

Rosenthal, M. (2016). Qualitative research methods: Why, when, and how to conduct interviews and focus groups in pharmacy research. Currents in Pharmacy Teaching and Learning, 8(4), 509-516.

Shumaker, H. (2016). Homework is Wrecking our Kids: The Research is Clear, Let's Ban Elementary Homework https://www.salon.com/2016/03/05/homework_

is_wrecking_our_kids_the_research_is_clear_lets_ban_elementary_homework

Silinskas, G., \& Kikas, E. (2019). Parental Involvement in Math Homework: Links to Children's Performance and Motivation, Scandinavian Journal of Educational Research, 63:1, 17-37, https://doi.org/10.1080/00313831.2017.1324901

Silinskas, G., Niemi, P., Lerkkanen, M.-K., \& Nurmi, J.-E. (2013). Children's poor academic performance evokes parental homework assistance - but does it help? International Journal of Behavioral Development, 37(1), 44-56. https://doi.org/10.1177/0165025412456146.

Snead, D., \& Burris, K. G. (2016). Middle School Teachers' Perceptions Regarding the Motivation and Effectiveness of Homework Journal of Inquiry \& Action in Education, 7(2), 2016

Tam, V.C., \& Chan, R. M. C. (2016). What Is Homework For? Hong Kong Primary School Teachers' Homework Conceptions 
Valle, A., Regueiro, B., Nuñez, J., Rodriguez, S., Piñeiro, I., \& Rosario, P. (2016). Academic goals, student homework engagement, and academic achievement in primary education. Frontiers in Psychology

Walker, T. (2017). If Elementary Schools Say No to Homework, What Takes Its Place? https://neatoday.org/2017/01/26/no-homework-policy/

Wilder, S. (2014). Effects of parental involvement on academic achievement: a metasynthesis. Educational Review, 66(3), 377-397. https://doi.org/10.1080/00131911.2013.780009 